\title{
Gambaran Ketidaklengkapan Pengisian Formulir Laporan Anestesi Kasus Bedah Di RSU Imelda Pekerja Indonesia Medan
}

\author{
${ }^{1}$ Valentina, ${ }^{2}$ Sri Mulia Melayu \\ Program Studi D-III Perekam dan Informasi Kesehatan, Universitas Imelda Medan
}

\begin{tabular}{l} 
Article Info \\
\hline Article history: \\
Received August 4, 2020 \\
Revised August 18, 2020 \\
Accepted August 29, 2020 \\
\hline
\end{tabular}

Keywords:

Incompleteness

Forms

Anesthesia

Surgical

Medical Record

\begin{abstract}
Every health service provided to patients must recorded in the medical records completely because the completeness of filling the medical record is used as an indicator of the quality of health services in the hospital. The purpose of this study is to determine the incomplete picture of filling out an anesthetic case report form in a surgical case at the Imelda Indonesian Workers Hospital in Medan. The type of research is descriptive. The populations of this study are all forms of anesthesia patient case reports for the first quarter of 2020 with a total of 728 forms. The samples are 88 forms taken using systematic random sampling. Data collection was carried out using the checklist sheet. Data were analyzed univariate to describe the characteristics of each research variable by producing a frequency distribution and percentage of each variable. The results showed that there were 24 anesthetized report forms that were completely filled and 64 anesthetic report forms that were not completely filled. The highest percentage of incompleteness of filling in the patient identity component on the item date of birth was 10 forms (11\%), on the anesthesia time component on the old surgical item by 39 forms (44\%), on the diagnostic component on the post-surgical diagnostic item by 28 forms (32\%), the examination component on the preoperative state item was 63 forms $(72 \%)$ and the signature component was 2 forms (2\%). It is recommended that every health worker who provides health services to surgical case patients fill out the anesthetic report form in accordance with the SPO authorizing the medical record filling, and to the medical record officer to conduct an assembling or complete analysis of medical record documents.
\end{abstract}

This is an open access article under the CC BY-SAlicense.

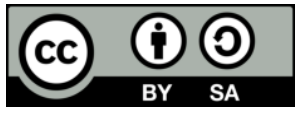

\section{Corresponding Author:}

Valentina,

Program Studi D-III Perekam dan Informasi Kesehatan,

Universitas Imelda Medan,

Jl. Bilal No. 52 Kelurahan Pulo Brayan Darat I Kecamatan Medan Timur, Medan - Sumatera Utara.

Email: valentinave89@gmail.com

\section{PENDAHULUAN}

Setiap pelayanan kesehatan yang diberikan kepada pasien harus terekam secara lengkap di dalam dokumen rekam medis, meliputi identitas pasien, pemeriksaan, tindakan, pengobatan, serta pelayanan lain yang telah diberikan kepada pasien (Permenkes RI, 2018). Standar pengisian dokumen rekam medis adalah 100\%, sehingga apabila catatan 
pelayanan kesehatan pasien tersebut tidak lengkap, maka akan merugikan pasien, tenaga kesehatan yang terlibat dalam pengisian rekam medis tersebut dan rumah sakit (Kepmenkes, 2008).

Kelengkapan dokumen rekam medis sangat berpengaruh terhadap proses pelayanan kesehatan di rumah sakit, karena kelengkapan pengisian rekam medis tersebut dijadikan sebagai salah satu indikator kualitas pelayanan, sehingga rekam medis yang tidak lengkap dapat mempengaruhi dokter atau perawat dan tenaga kesehatan lainnya dalam memberikan rencana pengobatan selanjutnya (Lubis, 2017). Selain itu kelengkapan pengisian rekam medis tersebut erat kaitannya dengan fungsi keuangan dalam proses pengklaiman serta fungsi hukum yakni sebagai alat bukti hukum berupa tulisan atau dokumen apabila terjadi sengketa atau perkara konflik hukum di pengadilan. Jika dokumen rekam medis yang tidak lengkap, petugas akan mengalami kesulitan dalam melakukan evaluasi terhadap pelayanan medis yang diberikan sehingga tidak bisa dijadikan sebagai bukti pengadilan dan sebagainya (Febrianti dan Sugiarti, 2019).

Berdasarkan penelitian yang dilakukan oleh (Herfiyanti dan Ninda, 2019), di RSU Pindad Bandung diketahui kelengkapan pengisian formulir informent consent anestesi pasien rawat inap mencapai $77 \%$ formulir anestesi yang terisi lengkap dan 23\% formulir anestesi yang tidak lengkap. Data ketidaklengkapan yang paling banyak adalah adalah dari review pencatatan sebanyak 55 formulir atau $23,40 \%$, review autentifikasi 36 formulir atau $55 \%$ dan review laporan penting (isi informasi) 29 formulir atau 12,40\%. Untuk review identifikasi $100 \%$ sudah terisi lengkap.

Formulir laporan anestesi kasus bedah merupakan salah satu formulir yang digunakan untuk merekam pelayanan pembedahan pasien. Berdasarkan survei awal yang dilakukan di RSU Imelda Pekerja Indonesia Medan di instalasi rekam medis pada bagian analisis rekam medis, masih ditemukan formulir laporan anestesi kasus bedah pada dokumen rekam medis yang belum lengkap. Hal ini akan mempengaruhi kualitas mutu pelayanan rumah sakit dan rekam medis itu sendiri apabila sewaktu-waktu diperlukan kembali dalam berbagai hal seperti, riset maupun pengadilan.

\section{METODE PENELITIAN}

A. Jenis Penelitian

Jenis penelitan yang digunakan adalah deskriptif dengan desain cross sectional. Waktu penelitian dilakukan pada bulan Maret sampai Agustus 2020. Tempat penelitian ini dilakukan di RSU Imelda Pekerja Indonesia Medan.

B. Populasi

Populasi penelitian ini adalah seluruh formulir laporan anestesi pasien kasus bedah di RSU Imelda Pekerja Indonesia Medan periode triwulan I tahun 2020 dengan jumlah 728 formulir laporan anestesi kasus bedah.

C. Sampel

Perhitungan jumlah sampel menggunakan rumus slovin.

$n=\frac{N}{1+N e^{2}}$

$\mathrm{N}$ : jumlah populasi

$\mathrm{n}$ : jumlah sampel

e : batas toleransi kesalahan $(10 \%)$

$$
\begin{aligned}
& =\frac{72 \mathrm{~g}}{1+72 \mathrm{~g} \times(0,1)^{2}} \\
& =\frac{72 \mathrm{~s}}{1+72 \mathrm{~s} \times 0.01} \\
& =\frac{72 \mathrm{~g}}{\mathrm{8}, 2 \mathrm{~g}} \\
& =87,9 \approx 88
\end{aligned}
$$


Maka jumlah sampel dalam penelitian ini adalah 88 laporan anastesi pasien kasus bedah. Teknik pengambilan sampel menggunakan systematic random sampling, yaitu teknik pengambilan sampel berdasarkan kelang-kelang urutan pada anggota populasi dengan nilai interval 8 .

D. Instrumen Penelitian

Instrumen yang digunakan dalam penelitian ini adalah lembar chek list.

E. Cara Pengumpulan Data

Cara pengumpulan data yang digunakan adalah studi dokumentasi, dimana peneliti memeriksa dokumen rekam medis dan mencatat secara langsung kelengkapan pengisian identitas pasien, waktu anestesi, diagnosis, pemeriksaan, tindakan anestesi, tanda tangan.

F. Analisis Data

Analisis data dilakukan secara univariat yaitu untuk mendeskripsikan karakteristik setiap variabel penelitian dengan menghasilkan distribusi frekuensi dan persentase dari tiap variabel.

\section{HASIL DAN PEMBAHASAN}

\subsection{Hasil}

Hasil penelitian menunjukkan bahwa pada pengisian komponen identitas pasien paling banyak yang tidak lengkap adalah item tanggal lahir yaitu 10 formulir (11\%) sedangkan pada pengisian komponen waktu anastesi paling banyak yang tidak lengkap adalah item lama pembedahan yaitu 39 formulir (44\%). Untuk lebih lengkapanya dapat dilihat pada tabel 1.

Tabel 1. Frekuensi dan Distribusi Pengisian Komponen Identitas Pasien dan Waktu Anastesi Pada Formulir Laporan Anestesi Kasus Bedah di RSU Imelda Pekerja Indonesia Medan

\begin{tabular}{lllcccc}
\hline \multirow{2}{*}{ No. } & \multirow{2}{*}{ Komponen Pengisian } & \multicolumn{2}{c}{ Lengkap } & \multicolumn{2}{c}{ Tidak Lengkap } & \multirow{2}{*}{ Total } \\
\cline { 2 - 6 } & Identitas Pasien & f & \% & f & \% & \\
\hline & & & & & \\
\hline 1. & No. RM & 81 & 92 & 7 & 8 & 88 \\
\hline 2. & Nama & 81 & 92 & 7 & 8 & 88 \\
\hline 3. & Tgl. Lahir & 78 & 89 & 10 & 11 & 88 \\
\hline & Waktu Anastesi & & & & & \\
\hline 1. & Ruangan & 73 & 83 & 15 & 17 & 88 \\
\hline 2. & Tanggal & 67 & 76 & 21 & 24 & 88 \\
\hline 3. & Pukul & 70 & 80 & 18 & 20 & 88 \\
\hline 4. & Lama Pembiusan & 60 & 68 & 28 & 32 & 88 \\
\hline 5. & Lama Pembedahan & 49 & 56 & 39 & 44 & 88 \\
\hline
\end{tabular}

Pengisian komponen diagnosis paling banyak yang tidak lengkap adalah pascabedah yaitu 28 formulir (32\%) sedangkan pada pengisian komponen pemeriksaan paling banyak yang tidak lengkap adalah status fisik ASA yaitu 36 formulir (41\%), item penyulit pra anastesi yaitu 59 formulir (67\%), penilaian pra induksi yaitu 61 formulir (69\%), dan keadaan pra bedah yaitu 63 formulir (72\%). Untuk lebih lengkapnya dapat dilihat pada tabel 2. 
Tabel 2. Distribusi Frekuensi Pengisian Komponen Diagnosis dan Pemeriksaan Pada Formulir Laporan Anestesi Kasus Bedah di RSU Imelda Pekerja Indonesia Medan

\begin{tabular}{|c|c|c|c|c|c|c|}
\hline \multirow{2}{*}{ No. } & \multirow{2}{*}{ Komponen Pengisian } & \multicolumn{2}{|c|}{ Lengkap } & \multicolumn{2}{|c|}{ Tidak Lengkap } & \multirow{2}{*}{ Total } \\
\hline & & $\mathbf{f}$ & $\%$ & $\mathbf{f}$ & $\%$ & \\
\hline & \multicolumn{6}{|l|}{ Diagnosis } \\
\hline 1. & Pra Bedah & 79 & 90 & 9 & 10 & 88 \\
\hline 2. & Pasca Bedah & 60 & 68 & 28 & 32 & 88 \\
\hline \multicolumn{7}{|c|}{ Pemeriksaan } \\
\hline 1. & Anamnesis & 81 & 92 & 7 & 8 & 88 \\
\hline 2. & Keadaan Pra Bedah & 25 & 28 & 63 & 72 & 88 \\
\hline 3. & Pemeriksaan Fisik & 64 & 73 & 24 & 27 & 88 \\
\hline 4. & Pemeriksaan Penunjang & 67 & 76 & 21 & 24 & 88 \\
\hline 5. & Status Fisik ASA & 52 & 59 & 36 & 41 & 88 \\
\hline 6. & Penyulit Pra Anestesi & 29 & 33 & 59 & 67 & 88 \\
\hline 7. & Check List Sebelum Induksi & 80 & 91 & 8 & 9 & 88 \\
\hline 8. & Monitoring & 58 & 66 & 30 & 34 & 88 \\
\hline 9. & Penilaian Pra Induksi & 27 & 31 & 61 & 69 & 88 \\
\hline 10. & Obat-Obatan /Infus & 86 & 98 & 2 & 2 & 88 \\
\hline 11. & Pemantauan & 86 & 98 & 2 & 2 & 88 \\
\hline 12. & Jenis Pembedahan & 86 & 98 & 2 & 2 & 88 \\
\hline
\end{tabular}

Pengisian komponen tindakan anastesi paling banyak yang tidak lengkap adalah teknik khusus yaitu 37 formulir (42\%), infus perifer yaitu 48 formulir (55\%) dan catatan yaitu 60 formulir $(68 \%)$. Sedangkan pada pengisian komponen tanda tangan terdapat 2 formulir (2\%) yang tidak diisi lengkap. Untuk lebih lengkapnya dapat dilihat pada tabel 3.

Tabel 3. Distribusi Frekuensi Pengisian Komponen Tindakan Anestesi dan Tanda Tangan Pada Formulir Laporan Anestesi Kasus Bedah di RSU Imelda Pekerja Indonesia Medan

\begin{tabular}{llccccc}
\hline \multirow{2}{*}{ No. } & \multirow{2}{*}{ Komponen Pengisian } & \multicolumn{2}{l}{ Lengkap } & \multicolumn{2}{c}{ Tidak Lengkap } & \multirow{2}{*}{ Total } \\
\cline { 2 - 5 } & & $\mathbf{f}$ & $\mathbf{\%}$ & $\mathbf{f}$ & $\mathbf{\%}$ & \\
\hline & Tindakan Anastesi & & & & & \\
\hline 1. & Teknik Anestesi & 86 & 98 & 2 & 2 & 88 \\
\hline 2. & Teknik Khusus & 51 & 58 & 37 & 42 & 88 \\
\hline 3. & Infus Perifer & 40 & 45 & 48 & 55 & 88 \\
\hline 4. & Posisi & 86 & 98 & 2 & 2 & 88 \\
\hline 5. & Premedikasi & 71 & 81 & 17 & 19 & 88 \\
\hline 6. & Induksi & 74 & 84 & 14 & 16 & 88 \\
\hline 7. & Intubasi & 81 & 92 & 7 & 8 & 88 \\
\hline 8. & Ventilasi & 81 & 92 & 7 & 8 & 88 \\
\hline 9. & Teknik Regional & 80 & 91 & 8 & 9 & 88 \\
\hline 10. & Catatan & 28 & 32 & 60 & 68 & 88 \\
\hline & Tanda Tangan & & & & & \\
\hline 1. & Spesialis Anestesi & 86 & 98 & 2 & 2 & 88 \\
\hline 2. & Spesialis Bedah & 86 & 98 & 2 & 2 & 88 \\
\hline 3. & Perawat Anestesi & 86 & 98 & 2 & 2 & 88 \\
\hline
\end{tabular}

\subsection{Pembahasan}


Berdasarkan hasil penelitian diketahui bahwa persentase tertinggi ketidaklengkapan pengisian komponen identitas pasien pada formulir laporan anestesi kasus bedah adalah pada item tanggal lahir sebesar 10 formulir (11\%). Identitas pasien yang diisi dengan lengkap dan benar dibutuhkan untuk memastikan milik siapa lembaran formulir tersebut sehingga dapat menjadi alat untuk identifikasi pasien secara spesifik. (Swari, dkk., 2019). Umur merupakan salah satu item yang dapat mempermudah petugas dalam proses pengidentifikasian pasien. Penulisan umur secara detail pada formulir rekam medis akan sangat berpengaruh terhadap pelayanan kesehatan pasien, terutama didalam bidang kefarmasian, dikarenakan umur dapat menentukan dosis obat, dalam penelitian ini obat anastesi yang tepat untuk dapat diberikan kepada pasien (Maliki, dkk., 2018)

Berdasarkan hasil penelitian diketahui bahwa persentase tertinggi ketidaklengkapan pengisian komponen waktu anestesi pada formulir laporan anestesi kasus bedah adalah pada item lama pembedahan yaitu 39 formulir (44\%). Kelengkapan pengisian waktu dalam setiap formulir mengacu pada Peraturan Menteri Kesehatan Tentang Rekam Medis 269/MENKES/PER/III/2008 pada pasal 5 ayat 4, bahwa setiap pencatatan kedalam rekam medis harus dibubuhi waktu dan tanda tangan dokter, dokter gigi, atau tenaga kesehatan tertentu yang memberikan pelayanan kesehatan secara langsung. Setiap pelayanan kesehatan yang diberikan kepada pasien wajib mengisi waktu dimulainya tenaga kesehatan yang bersangkutan memberikan pelayanan sampai pelayanan yang diberikan tersebut selesai pada rekam medis.

Berdasarkan hasil penelitian diketahui bahwa persentase tertinggi ketidaklengkapan pengisian komponen diagnosis pada formulir laporan anestesi kasus bedah adalah pada item diagnosis pasca bedah sebesar 28 formulir (32\%). Diagnosis adalah hasil dari evaluasi dan temuan dari pemeriksaan kesehatan pasien. Jika item diagnosis tidak terisi maka pelayanan seperti penentuan kode penyakit akan menjadi terhambat, dan tentunya akan berpengaruh terhadap proses klaim asuransi kesehatan seperti halnya program BPJS yang mengguanakan indikator kode diagnosis dalam menghitung tanggungan biaya pasien. Selain itu apabila diagnosis tidak terisi lengkap akan mengakibatkan penyakit yang diderita pasien tidak dapat diidentifikasi dengan tepat serta dapat menimbulkan kerugian baik bagi pasien maupun bagi rumah sakit (Maliki, dkk., 2018).

Berdasarkan hasil penelitian diketahui bahwa pencatatan setiap pemeriksaan yang dilakukan kepada pasien belum sesuai dengan SPO kewenangan pengisian rekam medis di RSU Imelda Pekerja Indonesia Medan, yaitu dengan persentase tertinggi ketidaklengkapan pengisian komponen pemeriksaan pada formulir laporan anestesi kasus bedah adalah pada status fisik ASA yaitu 36 formulir (41\%), item penyulit pra anastesi yaitu 59 formulir (67\%), penilaian pra induksi yaitu 61 formulir (69\%), dan keadaan pra bedah yaitu 63 formulir $(72 \%)$. Kelengkapan dalam pengisian komponen pemeriksaan sangat penting untuk mempersiapkan kondisi pasien sebelum pembedahan dan tindakan yang dilakukan oleh dokter dan tenaga kesehatan lain pada saat proses pembedahan. Untuk itu dokumen rekam medis diharapkan memuat informasi yang akurat, lengkap, dan dapat dipercaya (Susanto, dkk, 2015). Apabila laporan penting tidak terisi lengkap maka tidak akan ada pengobatan dan tindakan selanjutnya pada kasus bedah (Febriyanti dan Sugiarti, 2015).

Berdasarkan hasil penelitian diketahui bahwa persentase tertinggi ketidaklengkapan pengisian komponen tindakan anestesi pada formulir laporan anestesi kasus bedah adalah pada teknik khusus yaitu 37 formulir (42\%), infus perifer yaitu 48 formulir (55\%) dan catatan yaitu 60 formulir (68\%). Setiap tindakan yang diberikan kepada pasien wajib mengisi rekam medis karena rekam medis tersebut erat kaitannya dengan fungsi keuangan dalam proses pengklaiman serta fungsi hukum yakni sebagai alat bukti hukum berupa tulisan atau dokumen apabila terjadi sengketa atau perkara konflik hukum di pengadilan sesuai dengan Peraturan Menteri Kesehatan Tentang Rekam Medis Nomor 269/MENKES/PER/III/2008 pada pasal 10 ayat 2 bagian $b$, informasi tentang identitas, 
diagnosis, riwayat penyakit, riwayat pemeriksaan dan riwayat pengobatan dapat dibuka dalam hal memenuhi permintaan aparatur penegak hukum dalam rangka penegakan hukum atas perintah pengadilan. Apabila terdapat item yang memang tidak membutuhkan catatan dari dokter dan tenaga lainnya sebaiknya tetap diisi dengan tanda garis, atau ditulis "tidak ada".

Berdasarkan hasil penelitian diketahui bahwa persentase ketidaklengkapan pengisian komponen tanda tangan pada formulir laporan anestesi kasus bedah adalah pada semua item secara keseluruhan terdapat 2 formulir (2\%) yang belum diisi lengkap. Rekam medis sebagai bukti tulisan dapat dikatakan otentik karena kedudukan rekam medis dibuat dan di tandatangani oleh pejabat yang berwenang (dokter) karena mempunyai kedudukan tingkat keterbuktian yang kuat, jelas dan meyakinkan. Pengisian autentifikasi harus di isi dengan lengkap, terutama pada kasus atau tindakan yang beresiko tinggi, harus terdapat tanda tangan dari pihak dokter maupun pemberi persetujuan lainnya. Apabila dalam pengisian autentifikasi tidak lengkap ini merupakan salah satu ketidakdisiplinan dan tanggung jawab pihak dokter (Febriyanti dan Sugiarti, 2015). Dalam autentifikasi tidak boleh tanda tangani oleh orang lain selain dari penulisnya (Hasibuan \& Malau, 2019). Hal tersebut sesuai dengan Peraturan Menteri Kesehatan Tentang Rekam Medis Nomor 269/MENKES/PER/III/2008 pada pasal 5 ayat 4, setiap pencatatan kedalam rekam medis harus dibubuhi nama, waktu dan tanda tangan dokter, dokter gigi, atau tenaga kesehatan tertentu yang memberikan pelayanan kesehatan secara langsung.

\section{KESIMPULAN}

Berdasarkan hasil penelitian yang dilakukan di RSU Imelda Pekerja Indonesia Medan, maka dapat disimpulkan bahwa dengan jumlah sampel 88 formulir laporan anestesi kasus bedah terdapat 24 formulir laporan anestesi yang terisi lengkap dan 64 formulir laporan anestesi yang tidak terisi lengkap. Persentase tertinggi ketidaklengkapan pengisian pada komponen identitas pasien pada item tanggal lahir sebesar 10 formulir (11\%), pada komponen waktu anestesi pada item lama pembedahan sebesar 39 formulir (44\%), pada komponen diagnosis pada item diagnosis pasca bedah sebesar 28 formulir (32\%), pada komponen pemeriksaan pada item keadaan pra bedah sebesar 63 formulir (72\%) dan pada komponen tanda tangan yaitu sebesar 2 formulir (2\%).

\section{REFERENCES}

Febrianti LN, Sugiarti I. 2019. Kelengkapan Pengisian Formulir Laporan Operasi Kasus Bedah Obgyn Sebagai Alat Bukti Hukum. Jurnal Manajemen Informasi Kesehatan Indonesia. Vol. 7. No. 1. Maret 2019: 1-9.

Febriyanti IM, Sugiarti I. 2015. Analisis Kelengkapan Pengisian Data Formulir Anamnesis Dan Pemeriksaan Fisik Kasus Bedah. Jurnal Manajemen Informasi Kesehatan Indonesia. Vol. 3. No. 1. Maret 2015: 31-37.

Hasibuan, A. S., \& Malau, G. (2019). Ketidak Lengkapan Dokumen Rekam Medis Rawat Inap pada Pasien Diabetes Mellitus di RSU Imelda Medan. Jurnal Ilmiah Perekam Dan Informasi Kesehatan Imelda, 4(2), 675-679. http://jurnal.uimedan.ac.id/index.php/JIPIKI/article/view/92/95

Herfiyanti L, Ninda RC. 2019. Pengaruh Kelengkapan Pengisian Formulir Informed Consent Anestesi Pasien Rawat Inap Terhadap Pemenuhan Standar Nasional 
Akreditasi Rumah Sakit (SNARS-1) HPK 5.2 di Rumah Sakit Umum Pindad Bandung. Teras Kesehatan. Vol. 1. No. 2. Januari 2019: 89-98.

Kemenkes RI. 2008. Peraturan Menteri Kesehatan No. 269/MENKES/PER/III/2008. Rekam Medis. Jakarta: Kemenkes RI.

Keputusan Menteri Kesehatan RI No. 129/Menkes/SK/II/2008. Standar Pelayanan Minimal Rumah Sakit. Jakarta: Kemenkes RI.

Lubis, F. (2017). Tinjauan Ketidaklengkapan Penulisan Resume Medis Rawat Inap Di Rumah Sakit Umum Imelda Pekerja Indonesia (IPI) Medan Tahun 2016. Jurnal Ilmiah Perekam Dan Informasi Kesehatan, 2(1), 229-234. http://jurnal.uimedan.ac.id/index.php/JIPIKI/article/view/34/35

Maliki A, Saimi, Purnama H. 2018. Analisis Ketidaklengkapan Dokumen Rekam Medis Pada Kasus Rawat Inap di RSUD Patut Patuh Patju Gerung. Jurnal Kesehatan Qamarul Huda. Vol. 6. No. 1. Juni 2018: 17-23.

Peraturan Menteri Kesehatan RI No. 4 Tahun 2018. Kewajiban Rumah Sakit dan Kewajiban Pasien. Jakarta: Kemenkes RI.

Swari SJ, Alfiansyah G, Wijayanti RA, Kurniawati RD. 2019. Analisis Kelengkapan Pengisian Berkas Rekam Medis Pasien Rawat Inap RSUP Dr. Kariadi Semarang. Jurnal Ilmu Kesehatan. Vol. 1. No. 1. Nopember 2019: 50-56.

\section{BIOGRAPHIES OF AUTHORS}

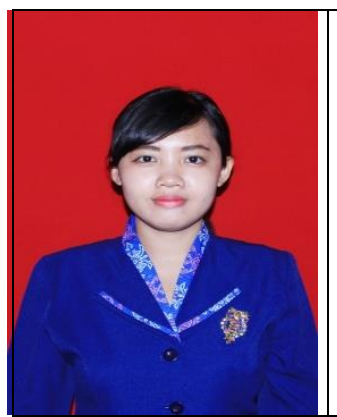

Valentina, Gelar Sarjana dari FKM Universitas sumatera Utara pada tahun 2011. Magister Kesehatan Masyarakat diperoleh dari FKM USU pada tahun 2015. Saat ini aktif sebagai pengajar di Program Studi D-III Perekam dan Informasi Kesehatan Universitas Imelda Medan. 